Article

\title{
Supplying Energy to Vulnerable Segments of the Population: Macro-Financial Risks and Public Welfare
}

\author{
Elena Smirnova ${ }^{1}$, Katarzyna Szczepańska-Woszczyna ${ }^{2, * \mathbb{D}}$, Saltanat Yessetova ${ }^{3}$ (D), Vadim Samusenkov ${ }^{4}$ and \\ Rodion Rogulin 5,6
}

1 Department of Taxes and Tax Administration, Financial University under the Government of the Russian Federation, 129347 Moscow, Russia; elenasmirnova@mail.ru

2 Department of Management, Faculty of Applied Sciences, WSB University, 41-300 Dabrowa Górnicza, Poland

3 Center for Social and Business Studies, University of International Business, Almaty 050000, Kazakhstan; saltanat.yessetova@gmail.com

4 Department of Prosthetic Dentistry, I.M. Sechenov First Moscow State Medical

University (Sechenov University), 119991 Moscow, Russia; croc@bk.ru

5 Department of Applied Mathematics, Mechanics, Controlling and Software, Far Eastern Federal University, 690089 Vladivostok, Russia; rafassiaofusa@mail.ru

6 Department of Mathematics and Modeling, Vladivostok State University of Economics and Service, 690014 Vladivostok, Russia

* Correspondence: kszczepanska@wsb.edu.pl

check for

updates

Citation: Smirnova, E.;

Szczepańska-Woszczyna, K.;

Yessetova, S.; Samusenkov, V.;

Rogulin, R. Supplying Energy to

Vulnerable Segments of the

Population: Macro-Financial Risks

and Public Welfare. Energies 2021, 14,

1834. https://doi.org/10.3390/

en14071834

Academic Editor: Marek Szarucki

Received: 3 February 2021

Accepted: 18 March 2021

Published: 25 March 2021

Publisher's Note: MDPI stays neutral with regard to jurisdictional claims in published maps and institutional affiliations.

Copyright: (c) 2021 by the authors. Licensee MDPI, Basel, Switzerland. This article is an open access article distributed under the terms and conditions of the Creative Commons Attribution (CC BY) license (https:// creativecommons.org/licenses/by/ $4.0 /)$.

\begin{abstract}
The purpose of the study is to assess the level of energy supply to the population of the Eastern Europe, Caucasus, and Central Asian (EECCA) countries, taking into account their financial risk and energy efficiency for households as potential socially vulnerable consumers. The research methodology is based on three approaches to determining the energy poverty of the population, as well as the integral index of energy supply to socially vulnerable segments of the population. Based on the results of the three approaches to assessing the level of energy supply to the population of EECCA countries, it has been revealed that its critical indicators are found in Armenia, Georgia, Kyrgyzstan, Moldova, Tajikistan, Turkmenistan, and Ukraine. The multivariate analysis of variance has revealed that, in all EECCA countries, both financial risk and energy efficiency levels have a significant impact. In Azerbaijan, Kazakhstan, and Russia, financial risk has the greatest impact on the level of energy supply to socially vulnerable segments of the population, while in other EECCA countries the energy efficiency factor has the strongest impact. In a number of EECCA countries, households have poor energy supply and require efficient and reliable operation, the introduction of energy-efficient technologies for home maintenance, and the improvement of related programs. The novelty of this study lies in the proposed methodological approach to assessing the supply of energy resources to socially unprotected segments of the population, which makes it possible to determine the impact of financial risk and energy efficiency in EECCA countries.
\end{abstract}

Keywords: analysis of variance; energy efficiency; energy poverty; energy supply; financial risk; household; tax

\section{Introduction}

One of the essential prerequisites for achieving the successful socio-economic development of countries and regions lies in creating a comprehensive and effective management system with efficient mechanisms for resource redistribution between different strata of the population. The provision of social assistance and social services to relevant beneficiaries, vulnerable segments and other groups of the population not only helps the state to prevent individuals and their families from living below the poverty line, but also to equally slow down a decrease in aggregate demand, thereby reducing the potential depth of the recession and the post-crisis state of the economy and increasing the economic potential [1]. 
On the path to the global energy market liberalization, in the context of setting economically justified tariffs for all consumers, including households, and reducing domestic energy consumption, social protection systems of individual states are not able to provide effective protection of consumers from the side effects of the process. The major prerequisites for this are fuel and energy price fluctuations and growth, as well as ineffective social policy, which requires urgent changes and improvements [2]. An increase in the efficiency and effectiveness of energy demand is becoming a crucial factor that is associated with the attraction of consumers who cannot support energy demand [3]. Despite the progress in various studies assessing the socio-economic development of the global economy in the current context of economic instability, the methodology for assessing public welfare under the influence of liberalization of the energy market has not been properly developed. The concept of energy security in terms of the availability of energy resources for household consumption is of high relevance, and this served as the motivation for conducting the study. This research aims to determine the system of factors affecting public welfare in the context of the energy supply of the population being able to transform into a threat to the economic security of countries and regions. In this regard, there is a need for the development of the methodology aimed at assessing the level of energy poverty and identifying the factors of its formation, as well as determining the integral index of energy supply to socially vulnerable segments of the population. This remains an urgent task today, the resolution of which is expected to replenish the methodological tools for developing a mechanism ensuring the effectiveness of the social economy.

The problem of eliminating energy poverty can be solved only if the final state of one or another process is known with a given degree of accuracy. Thus, the methodological approaches to the actual calculation of the indicator of energy supply to socially vulnerable segments of the population have not been developed yet [4]. There is a need for the approaches that will determine the factors affecting the phenomenon under study. The study aims to eliminate this gap by developing a procedure for synthesizing optimal solutions to the problem of inadequate energy supply according to process control criteria based on obtaining an alternative description of the final state. Therefore, the development of a methodology for studying this phenomenon in the socio-economic system of countries of Eastern Europe, the Caucasus, and Central Asia (EECCA) and identifying solutions to the problems of socially vulnerable consumers of fuel and energy resources in the context of the liberalization of energy markets is a pressing concern. All the above determined the purpose of this research, lying in the assessment of the level of energy supply to the EECCA countries' population with reference to the financial risk and energy efficiency of households as potential socially vulnerable consumers. To achieve this goal, the following key hypotheses have been formulated:

Hypothesis 1 (H1). The level of financial risk of households affects the level of energy supply to the population of the studied countries.

Hypothesis 2 (H2). The level of energy efficiency of households affects the level of energy supply to the population of the studied countries.

To confirm or reject these hypotheses, this study was built according to the following logic:

- Firstly, an assessment was made of population energy supply in the EECCA countries, according to the indicators of residual income and energy costs.

- Secondly, a diagnosis of population energy supply in the EECCA countries was carried out on the basis of $60 \%$ of the average regional income after deducting the cost of fuel and house maintenance.

- Thirdly, the integral index of energy supply to socially unprotected population segments in the studied countries was modeled. 
- Fourthly, in order to determine the relationship of the studied indicators with the level of EECCA countries' well-being, a comparative analysis of the index of energy supply to socially unprotected population segments and the prosperity index was performed.

- Fifthly, the influence of the financial risk and energy efficiency index on the level of energy supply to socially vulnerable population groups in the EECCA countries was determined on the basis of factorial analysis of variance.

\section{Literature Review}

A reliable, safe, environmentally acceptable, and sufficient energy supply to the population concerns all countries and regions of the world. Moreover, the deepening of regional differentiation (including in terms of energy supply to the population) is defined as a threat to the country's security [5]. At the same time, the problem of preserving the environment has acquired a large-scale character, which is due to the globalization of the world economy [6]. The forms of its manifestation are very diverse, but they all lead not only to an increase in the impact on the environment, but also to an increase in the problem of energy supply for the population as a whole. Nevertheless, as a result of the use of energy resources, the ecological environment is under pressure of such a high force that the conditions of human existence are beginning to change. Taking into account the need to save energy resources, the development of alternative energy sources is an important factor not only for environmental protection, environmental safety, and ensuring global goals of sustainable development $[7,8]$. Providing favorable conditions for the use of renewable energy sources (RES) will help to improve the level of environmental and economic efficiency and redistribution of energy resources. The development of alternative energy sources, in particular solar power plants, solves the problem of dependence on energy supplies from abroad, which helps to strengthen the energy security of countries and regions, and also contributes to an increase in the level of energy supply to the population [9]. An increase in the share of RES has a positive impact on energy security in those EECCA countries, which act according to planned energy development and energy transformation scenarios. In this case, the possibility of reducing energy dependence and strengthening energy security is proved [10]. However, at the same time, the social component of energy security is often ignored, which underlies the ground for this study to be focused on assessing the provision of energy resources to socially unprotected population segments. Along with the development of the scale of RES, another problem becomes more apparent. The growth in RES capacities while maintaining high green tariff rates can lead to a smooth rise in prices for electricity. The reimbursement of the enhanced green tariffs is conditional upon the increase in average prices for energy generated from both traditional and renewable sources. Therefore, a situation arises when the rising green tariff is compensated by applying higher prices on all energy consumers, and only a few gain profit from such tariff escalation [11]. The expansion of the country's renewable energy sector with the aim of maintaining sufficiently high green tariffs is fraught with the deepening of social problems associated with the stratification of the country's population by income level [12]. Therefore, this study is of particular relevance in the context of the social component of the country's energy security due to its focus on energy resources accessibility for the poor.

Overcoming the contradiction between the need to ensure social protection of lowincome population segments and introduce market principles of management in the energy sector requires improving social policy. Energy efficiency and energy-saving measures in the residential sector have a particularly noticeable effect on the health of the population and the associated social consequences [13]. Improving energy efficiency and energy saving in the construction industry can improve the health of residents of residential buildings, office workers, many other groups, and the general population [14,15]. Health impacts are equally related to energy-efficient housing and appliances [16].

With high energy prices and financial constraints, the poor often cannot afford enough energy services to maintain healthy living conditions. They are forced to under-heat their homes, which causes hypothermia, tolerate poor indoor air quality, and/or give up other 
basic necessities such as food. Energy efficiency can address this issue by taking householdlevel measures to reduce energy costs through insulation and design, supplying efficient appliances, equipment for space heating, hot water heating and lighting, and educating residents on energy efficiency $[17,18]$.

A common description of energy poverty is a situation where individuals or households are not able to adequately heat their homes or provide other energy services at affordable cost [19]. It has been generally recognized that energy poverty is one of the key social problems that states should address either through social policy or energy policy [20]. Energy poverty is an important political issue as it is a common fact that poorly heated or cooled homes have detrimental effects on the respiratory, circulatory and cardiovascular systems, as well as on mental health and well-being [21,22]. Energy poverty also has some broader economic and political impacts. Despite the fact that energy poverty is partly due to inadequate household income (energy poverty is noted among many low-income households), it does not completely overlap with income poverty and is a separate problem, which should be addressed through both energy policy and social policy [23]. Many developing countries suffer from heavy dependence on energy imports and inadequate rural electrification, which exacerbates the problem of poverty [24].

Energy poverty should be measured based on the combination of multiple indicators as it is a complex multidimensional problem that manifests itself in various ways in different households and states [25]. For example, there is an approach that assesses the latent aspect of energy poverty. It examines the lack of energy consumption by households due to low energy efficiency and budgetary constraints. A household is exposed to hidden energy poverty if the value of the total disposable income after the deduction of the expected housing costs falls below a specified threshold [26,27].

A household is in fuel poverty if its fuel costs are above average (national median) and the disposable income after fuel costs is below the official poverty line. In such a manner, population income, energy needs, and fuel prices represent the key components that should be considered to calculate fuel poverty status [28]. The most widely used methods to analyze energy poverty are the cost approach and the consensus approach. According to the cost approach, energy poverty is usually associated with low income and energy efficiency and high energy prices [29]. The consensus approach is used to quantify energy poverty in terms of subjective indicators [30]. On top of this, the global community often takes advantage of the multidimensional energy poverty index, which focuses on a set of energy deprivations that affects a person or household [31].

The COVID-19 pandemic has exacerbated financial difficulties of households related to energy costs. The pandemic has negatively affected the average disposable income of households, which has led to an increase in the share of disposable income spent on energy due to rising energy prices and costs. The poorest households were most seriously affected. In addition, the long-standing trend of declining energy poverty has reversed. COVID-19 has contributed to increased energy poverty [32].

Today, there is a negative correlation between economic development and energy poverty. Among the components of economic development, education has a greater impact on reducing energy poverty than income. Energy poverty and socio-economic backwardness are closely interrelated [33]. The optimal subsidy strategies for different countries depend on a number of factors, including social capital, the intensity of traditional energy emissions and the efficiency of renewable energy production, etc. [34]. In this regard, there is a need to form methodological developments on assessing the level of energy poverty and identifying the factors of its formation, as well as determining the integral index of providing energy resources to socially unprotected population segments. The latter is an urgent task in developing the mechanism for the functioning of a socially-oriented economy. This confirms the feasibility of this study, which consists in assessing the level of energy supply to the population of the EECCA countries, taking into account financial risk and energy efficiency for households as potential socially unprotected consumers. 


\section{Materials and Methods}

The research methodology is based on the approaches to establishing energy poverty and the opportunities to meet basic population needs for energy resources, namely: to maintain an adequate room temperature, to get energy for cooking, etc. It is assumed that households whose energy costs exceed the energy poverty threshold amount, which is $10 \%$, are considered energy poor [35]. In addition to energy costs, energy consumption, energy prices, and energy efficiency of households should be included in the determination of the threshold value for providing energy carriers to socially vulnerable segments of the population.

The study relies on the after-fuel-costs poverty criterion, which measures the residual household income after the deduction of fuel and housing costs and compares it to the poverty threshold, which is predominantly $60 \%$ of the region's average income after the deduction of fuel and housing costs [36]:

$$
\mathrm{PAFC}_{i}=\frac{R I_{i}}{\mathrm{RI} \cdot 60 \%}
$$

where $R I_{i}$ is the residual income of the average household per year in the $i$-country and $R I$ is the residual income of the average household per year in EECCA countries, wherein:

$$
R I_{i}=N H I_{i}-E I C_{i}
$$

where $\mathrm{NHI}_{i}$ is the net income of the average household per year in the $i$-country and $E I C_{i}$ is energy costs of an average household per year in the $i$-country, wherein:

$$
N H I_{i}=P C I_{i} \cdot H A S_{i}
$$

where $P C I_{i}$ is annual income per person in the $i$-country and $H A S_{i}$ is the average household size in the $i$-country [37].

The study relies on the average annual household income of the countries and its contrast to the total energy costs of the average household per year. Basically, this is the so-called income after fuel and energy costs. The total income of all EECCA countries has been determined based on the same pattern. By dividing the income after energy costs indicator by $60 \%$ of the total income after energy costs indicator of the EECCA countries, the indicator of the energy supply to socially vulnerable groups of the population after fuel and energy costs was determined.

The study also considered the criterion according to which a household can be considered energy poor if it has to spend more than $10 \%$ of its income to maintain adequate heating and receive all other energy services. This approach became the basis for determining the share of energy costs by the following formula:

$$
S E C_{i}=\frac{E I C_{i}}{N H I_{i}}
$$

According to this approach, a household is considered energy poor if it spends more than $10 \%$ of its income on energy to maintain a satisfactory thermal regime and receive other energy services. The approach limitation may relate to the fact that the determination of an adequate thermal regime requires a number of household surveys. In addition, households themselves can save energy. With due regard to this fact, the calculations performed in the study are based on the annual total energy expenditure of an average household in the country divided by its income. The indicator that exceeds 0.1 indicates that the household spends more than $10 \%$ of its income on energy. Therefore, it can be considered energy poor, that is, energy insecure.

When modeling the final indicator of household energy expenditure (FCi), the search for proper energy supply management involved heat, gas, electricity, peat, coal, firewood, liquefied butane and propane gas. The dynamics of the consumption of these resources by 
the household sector in 2019 in the context of the EECCA countries were analyzed, as well as the analysis of energy prices in 2019 was performed. The annual expenditures on the listed energy resources per one household were determined for the EECCA countries. The formula for the calculation of energy resources cost (ERC) is as follows:

$$
E R C_{i}=H_{i}^{e} \cdot H P+G_{i}^{e} \cdot G P+E_{i}^{e} \cdot E P+P_{i}^{e} \cdot P P+C_{i}^{e} \cdot C P+F_{i}^{e} \cdot F P+B_{i}^{e} \cdot B P
$$

where $H_{i}^{e}$ is the annual heat consumption by one household of the $i$-country, $G_{i}^{e}$ is the annual gas consumption by one household of the $i$-country, $E_{i}^{e}$ is the annual electricity consumption by one household of the $i$-country, $P_{i}^{e}$ is the annual peat consumption by one household of the $i$-country; $C_{i}^{e}$ is the annual coal consumption by one household of the $i$-country, $F_{i}^{e}$ is the annual firewood consumption by one household of the $i$-country; $B_{i}^{e}$ is the annual liquefied butane and propane consumption by one household of the $i$-country, and $H P, G P, E P, P P, C P, F P, B P$ are the prices for the energy resources.

As part of the study, in order to predict and examine the level of socio-economic development of the EECCA countries, an analytical macroeconomic model of the energy efficiency of the studied countries has been developed. Based on the systematic approach principles, a macroeconomic model for assessing energy poverty in the EECCA countries was constructed based on the monetary poverty indicator, which is expressed as a financial risk index and an energy inefficiency indicator. To calculate the financial risk indicator, the financial risk index of the population $\left(F R_{i}\right)$ was determined as the ratio of the income of an average household in EECCA countries to the average household income in a separate of the countries under study. Next, the maximum and minimum values of $F R$ were determined. Thus, the financial risk index for the period of 2019 is assumed as the ratio of the difference between the indicator of $F R$ for the country and the minimum value of $F R$ for all EECCA countries to the difference between the highest and lowest values of $F R$. The indicator of energy efficiency was determined by analogy. The indicator was calculated based on the consumption of all types of energy resources per one square meter of household in the country under study in terms of tonnes of fuel equivalent. The indicator of energy efficiency was determined similarly to the indicator of the financial risk index, which is described above.

In the study, the use of the integral index of energy supply to socially vulnerable segments of the population is proposed [38]. It takes into account two components, namely the financial risk index and energy inefficiency, and is calculated as their geometric mean, that is, the square root of their product. The integral energy supply index (IESI) reflects the level of energy supply to socially vulnerable segments of the population taking into account the contribution of each component. It is calculated as follows:

$$
I E S I_{i}=\sqrt{F R I_{i} \cdot E E I_{i}}
$$

where $I E S I_{i}$ is the index of household energy supply in the $i$-country for the corresponding period and $F R I_{i}$ is the integral index of financial risk of the $i$-country for the corresponding year, where:

$$
F R I_{i}=\frac{F R_{i}-\min \left(F R_{i}\right)}{\max \left(F R_{i}\right)-\min \left(F R_{i}\right)} .
$$

The financial risk indicator of the countries under study is defined as follows:

$$
F R_{i}=\frac{H I}{H I_{i}}
$$

where $H I$ is the income of an average household in EECCA countries for the study period and $H I_{i}$ is the income of an average household in the $i$-country for the same period. At the same time, $\min \left(F R_{i}\right)$ is the lowest level of financial risk and $\max \left(F R_{i}\right)$ is the highest level of 
financial risk among the countries under consideration for the studied period. The energy inefficiency indicator for the $i$-country $\left(E E I_{i}\right)$ is determined by the following formula:

$$
E E I_{i}=\frac{E E_{i}-\min \left(E E_{i}\right)}{\max \left(E E_{i}\right)-\min \left(E E_{i}\right)}
$$

where $E E_{i}$ is the energy inefficiency indicator, which is determined as the ratio of the consumption of energy resources by the average household in the EECCA countries per year in terms of the oil equivalent $\left(S q_{i}\right)$ in the $i$-country for the same year, $\min \left(E E_{i}\right)$ is the lowest energy inefficiency of all EECCA countries for the corresponding year, and $\max \left(E E_{i}\right)$ is the highest energy inefficiency of all studied countries for the corresponding year.

At the same time, this assumes:

$$
E E_{i}=H_{i}^{e} \cdot H C+G_{i}^{e} \cdot G C+E_{i}^{e} \cdot E C+P_{i}^{e} \cdot P C+C_{i}^{e} \cdot C C+F_{i}^{e} \cdot F C+B_{i}^{e} \cdot B C
$$

where $H_{i}^{e}$ is the annual heat consumption by one household of the $i$-country; $G_{i}^{e}$ is the annual gas consumption by one household of the $i$-country; $E_{i}^{e}$ is the annual electricity consumption by one household of the $i$-country; $P_{i}^{e}$ is the annual peat consumption by one household of the $i$-country; $C_{i}^{e}$ is the annual coal consumption by one household of the $i$-country; $F_{i}^{e}$ is the annual firewood consumption by one household of the $i$-country; $B_{i}^{e}$ is the annual liquefied butane and propane consumption by one household of the $i$-country; and $H C, G C, E C, P C, C C, F C, B C$ are the conversion factors of the corresponding type of energy resources into the oil equivalent.

In practice, the integral index of energy supply to socially vulnerable segments of the population proposed in this study demonstrates hidden energy poverty. With the intention of comparing the level of this indicator with the welfare of the studied countries, the present research presupposed contrasting the Prosperity Index developed by the Legatum Institute with the index of energy supply to socially vulnerable population groups. The major factors of the Prosperity Index incorporate economic growth, wealth, quality of life, health, education, and personal well-being [39].

To determine the effect of financial risk and energy efficiency on the level of energy supply to socially vulnerable segments of the EECCA countries' population, a factorial analysis of variance was carried out. The initial data for this examination were obtained on the basis of the assumption that the average level of financial risk and energy efficiency index may deviate by up to $10 \%$ (Table 1 ).

Table 1. Initial data for the analysis of variance of the impact of financial risk and energy efficiency on the level of energy supply to socially vulnerable groups of EECCA countries' population (fragment).

\begin{tabular}{cccc}
\hline Investigated Factors & $\begin{array}{c}\text { Average Level of } \\
\text { Financial risk (+8-10\%) }\end{array}$ & $\begin{array}{c}\text { Average Level of } \\
\text { Financial Risk (+5-7\%) }\end{array}$ & $\begin{array}{c}\text { Average Level of } \\
\text { Financial Risk (+2-4\%) }\end{array}$ \\
\hline Average energy efficiency index (+2\%) & 0.326 & 0.347 & 0.354 \\
Average energy efficiency index (+3\%) & 0.331 & 0.371 & 0.390 \\
Average energy efficiency index (+4\%) & 0.330 & 0.403 & 0.429 \\
Average energy efficiency index (+5\%) & 0.301 & 0.320 & 0.326 \\
Average energy efficiency index (+6\%) & 0.291 & 0.326 & 0.343 \\
Average energy efficiency index (+7\%) & 0.275 & 0.336 & 0.358 \\
Average energy efficiency index (+8\%) & 0.294 & 0.312 & 0.318 \\
Average energy efficiency index (+9\%) & 0.274 & 0.308 & 0.323 \\
Average energy efficiency index $(+10 \%)$ & 0.252 & 0.307 & 0.327 \\
\hline
\end{tabular}

Source: developed by the authors.

Baseline data for each country were generated similarly. Variations of the factors under consideration made it possible to analyze possible combinations and determine how much the level of energy supply to socially unprotected segments of the EECCA countries' population depends on them. 
The present study addresses financial risk as a threat of additional costs incurred by households, which entails negative financial consequences for the whole country. As such, financial risk implies the likelihood of unfavorable conditions for households in the context of losing part of their income or incurring extra expenditures.

Given the preceding information, the research process included the following main stages: (1) assessment of the population's energy supply in terms of residual income and energy costs; (2) assessment of the energy supply of the population of the studied countries based on $60 \%$ of the average regional income after deducting the cost of fuel and home maintenance costs; (3) determination of the index of energy supply to socially vulnerable segments of the population in the studied countries; (4) comparison of the Prosperity Index and the index of energy supply to socially vulnerable segments of the population; (5) conducting a factorial analysis of variance of the impact of the financial risk and energy efficiency on the level of energy supply to the socially vulnerable population of the EECCA countries.

\section{Results}

Based on the indicators of energy costs and residual income of households in the EECCA countries, it can be stated that energy poverty is observed in half of the countries under consideration. Armenia, Belarus, Georgia, Kyrgyzstan, Moldova, and Ukraine have already entered the critical zone, that is, the zone of high costs and low household income (the bottom-right corner of Figure 1). The main reason for this phenomenon was not only poor energy efficiency of households and their low income but also the rapid increase in fuel and energy prices. The effect of this factor is confirmed by the fact that energy poverty occurs when household expenditure on fuel and energy resources exceeds $10 \%$ of household income.

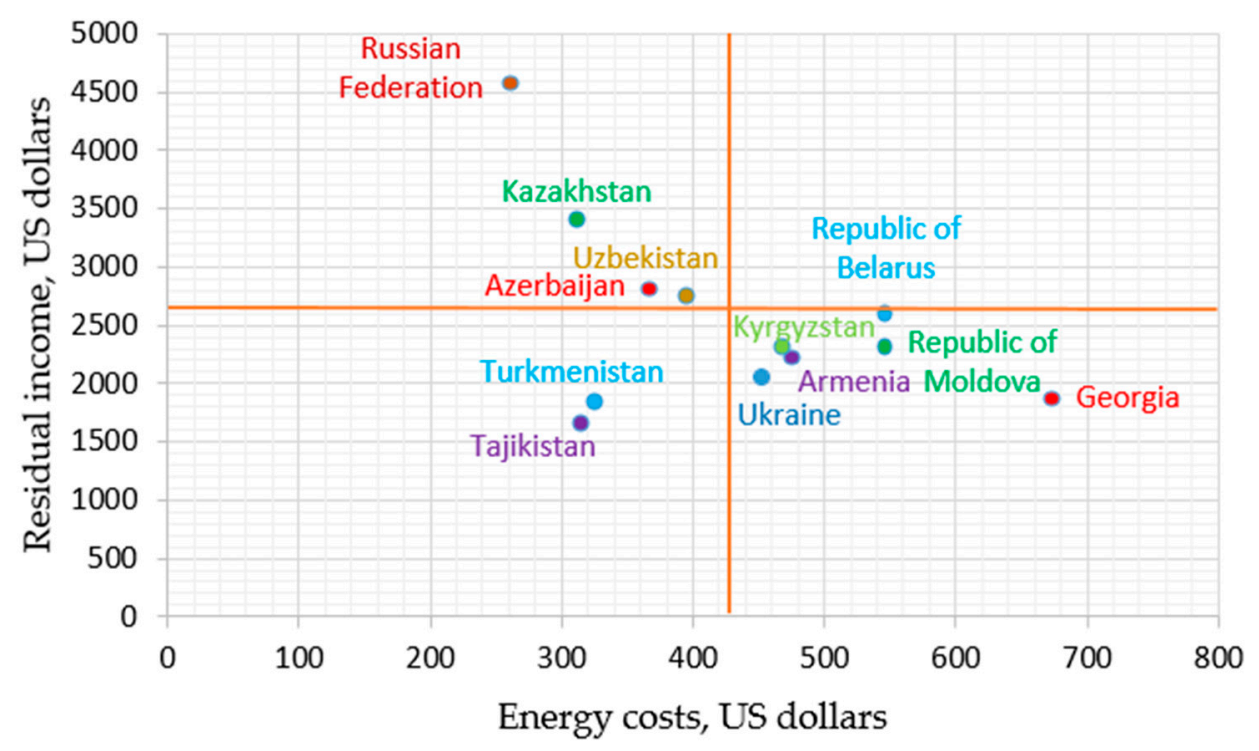

Figure 1. Indicators for assessing energy supply of the population of the EECCA countries. Source: authors' elaboration.

According to the calculations, most of the countries under study $(83 \%)$ have passed the $10 \%$ threshold of energy expenditure, that is, households in these countries have begun to spend more than $10 \%$ of their income on energy. In 2019, a low level of energy supply to the population was observed in Armenia, Azerbaijan, Kyrgyzstan, Belarus, Moldova, Tajikistan, Turkmenistan, Ukraine, Uzbekistan, and Georgia, which is characterized by the lowest level of the indicator. The population of Russia and Kazakhstan has adequate access to energy resources.

When considering the level of energy supply to the population based on another approach, according to which the phenomenon occurs when the residual household income 
after the deduction of fuel, energy, and housing costs is compared with $60 \%$ median income of the population in the EECCA countries, it can be argued that the greater the value of household income after the deduction of energy costs $(>1.6)$, the richer the country can be considered in the energy context and vice versa (Figure 2). Due to the fact that in such countries as Armenia, Azerbaijan, Belarus, Georgia, Kazakhstan, Kyrgyzstan, Moldova, Tajikistan, Turkmenistan, Ukraine, and Uzbekistan, the residual income of the average household after the deduction of energy costs was lower than the average residual income in the EECCA countries $(<1.6)$, they can be considered energy poor economies. According to the third approach that compares the household income threshold with the threshold of the average residual income across the EECCA countries, as well as the energy costs of an average household in a given country with the threshold of average household energy expenditure across the EECCA countries, countries such as Armenia, Georgia, Kyrgyzstan, Moldova, Tajikistan, Turkmenistan, and Ukraine are energy poor as their average household income is lower and the energy expenditure is higher than the regional averages. Moreover, it should be noted that if the comparison had been performed based on the standard and carefully studied household energy costs calculated according to all technical characteristics of household energy efficiency, which could be considered the norm, rather than the average regional income or average regional energy costs, the calculations would be much more accurate, and the indicator of the energy security of the population would be much lower. Due to the fact that critical indicators of energy supply to the population were found in the three approaches described in the study, it can be argued that Armenia, Georgia, Kyrgyzstan, Moldova, Tajikistan, Turkmenistan, and Ukraine are energy poor; thus, households in these states cannot meet basic energy needs, namely: proper temperature regime, adequate number of energy carriers to provide household services. At the same time, energy costs exceed a certain percentage of household income.

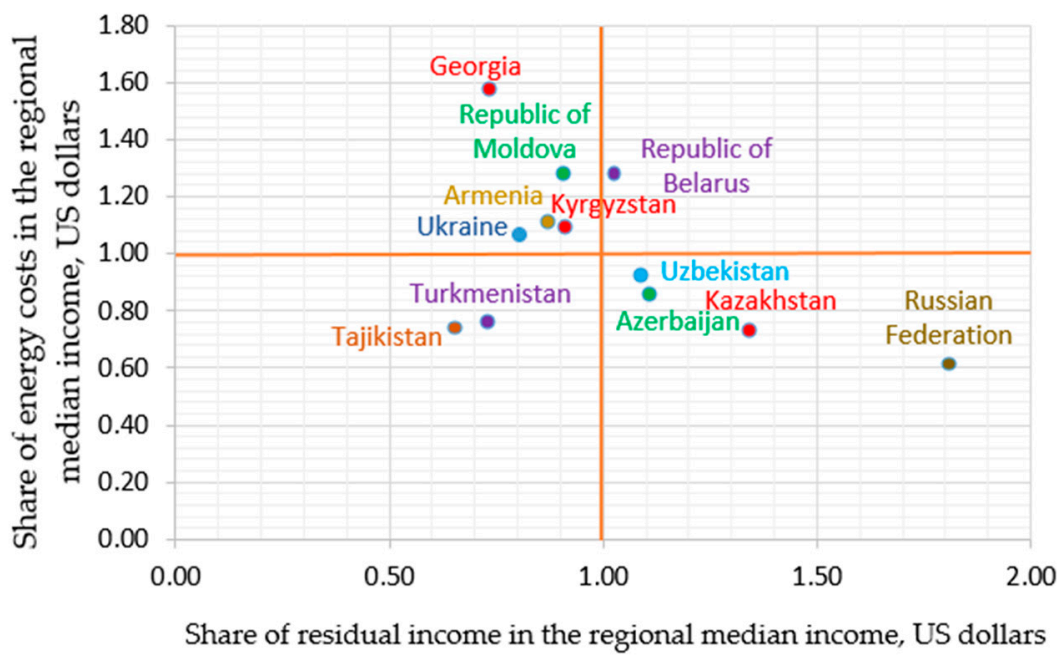

Figure 2. Assessment of the energy supply of the population of the EECCA countries (based on $60 \%$ of the regional median income after the deduction of fuel and housing costs). Source: authors' elaboration.

The calculation of the integral index of energy supply to socially vulnerable segments of the population allowed us to assess low-income countries that have a high level of consumption of fuel and energy resources. The results indicate that in most countries the financial risk index is higher than the energy efficiency index despite the fact that almost all countries under study are close to the energy poverty zone. At the same time, the integral index of energy security of the population of the countries can be an integral element of a socio-economic development strategy and indicate the problematic aspects of energy security in the EECCA region. In this fashion, the availability of energy resources for household consumption is of utmost importance in assessing countries' energy security. 
The integral energy security indicator shown in Figure 3 indicates the possibility of using macroeconomic policy instruments. It demonstrates the interaction of such important variables as household income, household energy consumption, average household size, number of households, population size, dynamics of energy prices with due regard to regional characteristics, and confirms its adequacy. In the EECCA countries, the energy supply index ranges from 0.43 to 0.65 . Moreover, the indicator is seriously affected by an increase in energy prices. The low index value confirms the low level of household income and the high energy costs in the EECCA countries. This approach provides more opportunities for modeling, forecasting, and examining economic systems in contrast to statistical approaches, and allows the assessment of the energy security of the region and separate countries. Based on this approach, it is possible to identify the most vulnerable social groups that need support to get out of energy poverty. The inadequate level of energy supply to the population in the EECCA countries is evidenced by the fact that most of the states $(67 \%)$ are at financial risk (the lower right corner of Figure 3) and some countries have already entered the zone of the upper right corner of the graph, which characterizes a lower level of energy consumption per unit area (i.e., energy efficiency) and a sufficient level of household income.

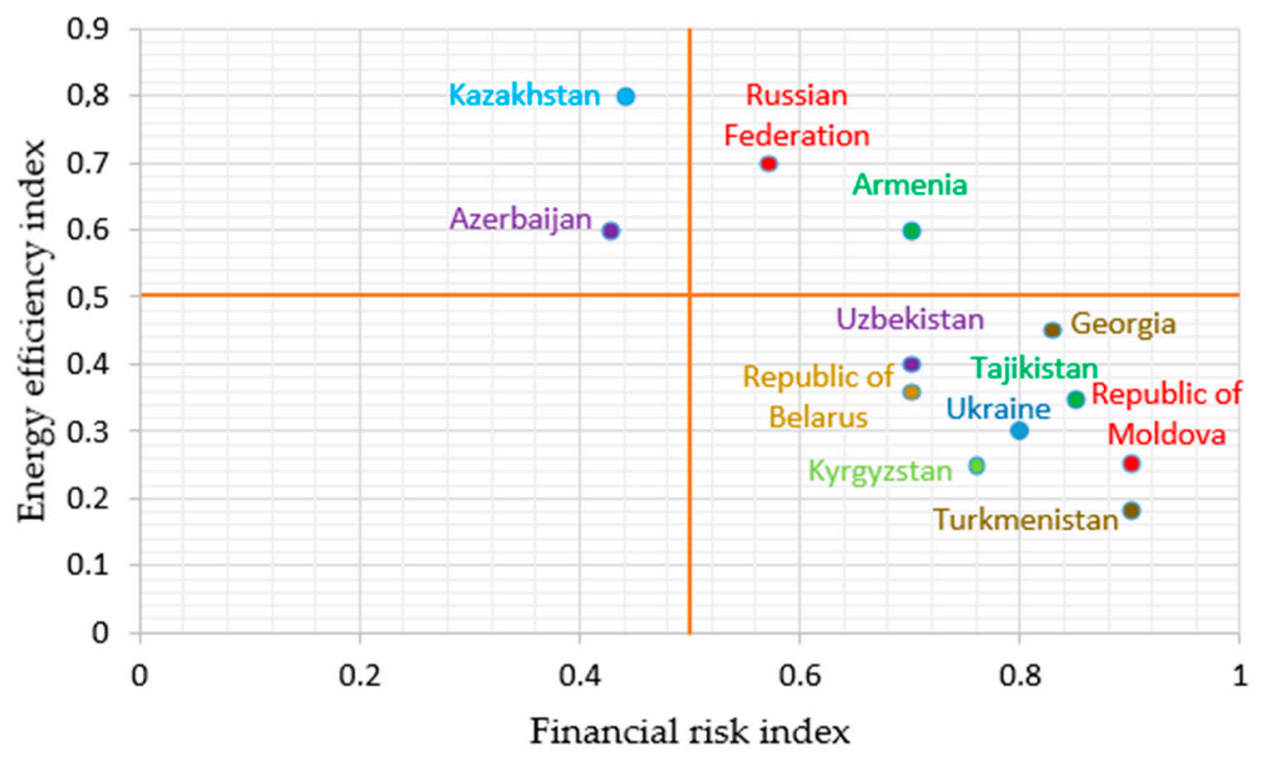

Figure 3. The results of modeling the integral index of energy supply to socially vulnerable segments of the population. Source: authors' elaboration.

To determine the threshold, the average data for the EECCA countries were considered. Low-income countries that have already entered the critical zone include Georgia, Belarus, Kyrgyzstan, Moldova, Tajikistan, Turkmenistan, Ukraine, and Uzbekistan. This value clearly indicates the non-market energy prices for the population and the high level of energy price subsidization. At the same time, in the EECCA countries, the income of the population cannot be described as high, and this shows the lack of a fully fledged market mechanism for pricing fuel and energy resources that are directly consumed by the population, as well as the lack of an effective social policy.

In order to determine the relationship between the energy supply to disadvantaged social groups and the well-being of the studied countries, the index of energy supply to socially vulnerable population segments and the Prosperity Index were compared (Figure 4). 


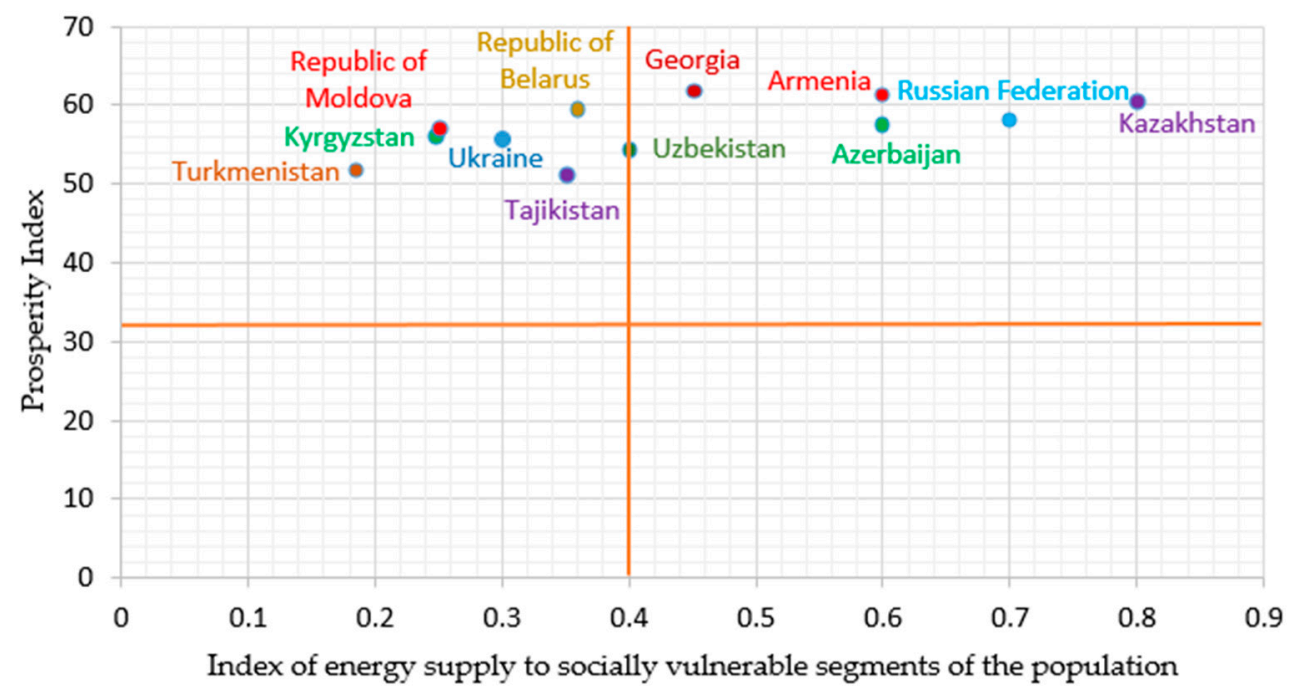

Figure 4. The ratio of the integral index of energy supply to socially vulnerable population segments and the level of well-being of the countries under consideration. Source: developed by the authors based on their own calculations of the energy supply index and the Prosperity Index [39].

A high level of energy supply to socially unprotected segments of the population is inherent to most EECCA countries with the highest prosperity. Hence, on the one hand, one can infer that the energy supply of socially vulnerable groups of the population does not threaten the welfare of the EECCA countries, but on the other, a sufficient energy supply to socially unprotected groups can be a characteristic feature of wealthy states.

To determine the influence of the factors under study (financial risk index and energy efficiency), a multivariate analysis of variance with repetitions was carried out (Table 2).

The multivariate analysis of variance has revealed that in all EECCA countries both financial risk and energy efficiency levels have a significant impact. This is proved by $p$-value $<0.005$ for EEI and FRI for all states and suggests the acceptance of H1 and H2. As a result, the conclusion can be made that these countries should not only ensure an adequate level of population income but also use energy resources in the context of their consumption efficiency. At the same time, the combination of these factors does not have a significant impact. The degree of influence of the factors discussed is shown in Figure 5.

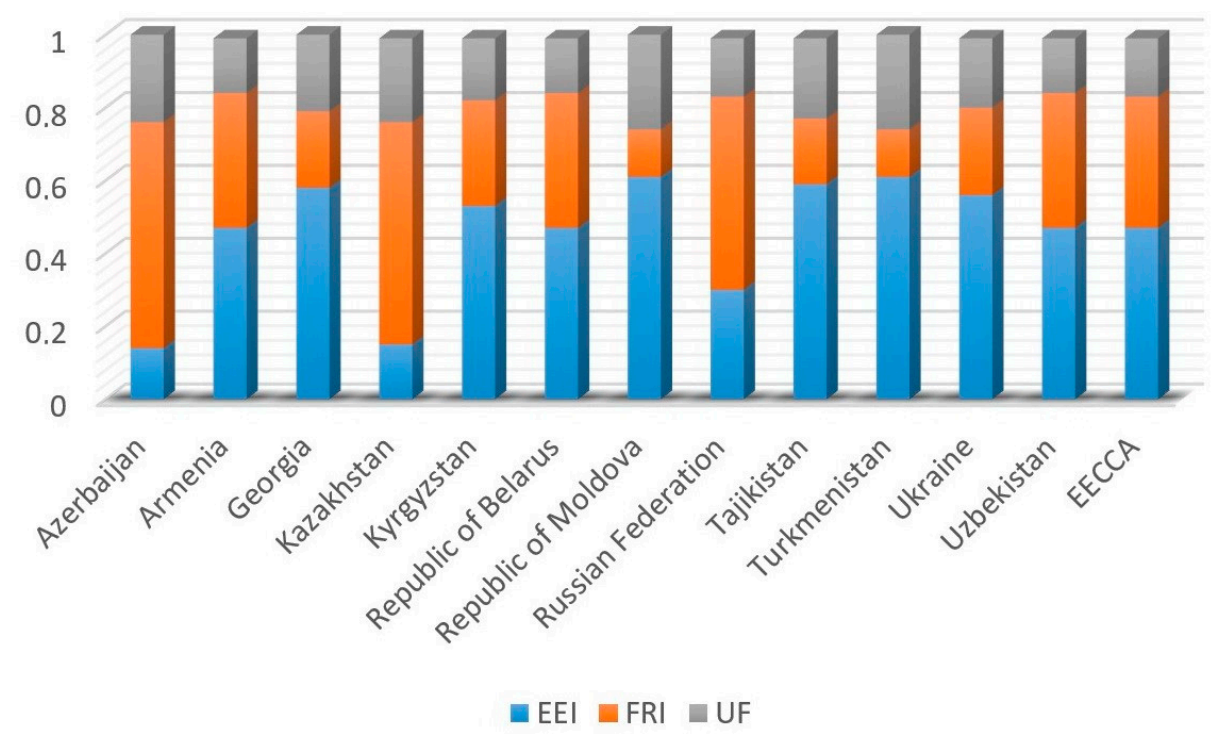

Figure 5. The influence of financial risk and energy efficiency indicators on the level of energy supply to socially vulnerable groups of the population of the EECCA countries. Source: authors' elaboration. 
Table 2. The indicators of the influence of the factors under study on the level of energy supply to socially vulnerable groups of the population of the EECCA countries.

\begin{tabular}{|c|c|c|c|c|c|c|}
\hline Region & Variation Source & SS & MS & $\mathbf{F}$ & $p$-Value & F Crit. \\
\hline \multirow{3}{*}{ EECCA } & EEI & 0.0025 & 0.0013 & 5.4318 & 0.0143 & 3.5546 \\
\hline & FRI & 0.0109 & 0.0055 & 23.3145 & 0.0000 & 3.5546 \\
\hline & Inter. & 0.0000 & 0.0000 & 0.0173 & 0.9994 & 2.9277 \\
\hline \multirow{3}{*}{ Azerbaijan } & EEI & 0.0025 & 0.0013 & 5.4318 & 0.0143 & 3.5546 \\
\hline & FRI & 0.0109 & 0.0055 & 23.3145 & 0.0000 & 3.5546 \\
\hline & Inter. & 0.0000 & 0.0000 & 0.0173 & 0.9994 & 2.9277 \\
\hline \multirow{3}{*}{ Armenia } & EEI & 0.0178 & 0.0089 & 28.2788 & 0.0000 & 3.5546 \\
\hline & FRI & 0.0141 & 0.0070 & 22.3626 & 0.0000 & 3.5546 \\
\hline & Inter. & 0.0001 & 0.0000 & 0.0900 & 0.9844 & 2.9277 \\
\hline \multirow{3}{*}{ Georgia } & EEI & 0.0348 & 0.0174 & 24.9139 & 0.0000 & 3.5546 \\
\hline & FRI & 0.0124 & 0.0062 & 8.8663 & 0.0021 & 3.5546 \\
\hline & Inter. & 0.0002 & 0.0001 & 0.0796 & 0.9876 & 2.9277 \\
\hline \multirow{3}{*}{ Kazakhstan } & EEI & 0.0028 & 0.0014 & 5.9174 & 0.0106 & 3.5546 \\
\hline & FRI & 0.0111 & 0.0056 & 23.8176 & 0.0000 & 3.5546 \\
\hline & Inter. & 0.0000 & 0.0000 & 0.0189 & 0.9992 & 2.9277 \\
\hline \multirow{3}{*}{ Kyrgyzstan } & EEI & 0.0247 & 0.0123 & 28.0154 & 0.0000 & 3.5546 \\
\hline & FRI & 0.0135 & 0.0068 & 15.3721 & 0.0001 & 3.5546 \\
\hline & Inter. & 0.0002 & 0.0000 & 0.0894 & 0.9846 & 2.9277 \\
\hline \multirow{3}{*}{ Republic of Belarus } & EEI & 0.0178 & 0.0089 & 28.2788 & 0.0000 & 3.5546 \\
\hline & FRI & 0.0141 & 0.0070 & 22.3626 & 0.0000 & 3.5546 \\
\hline & Inter. & 0.0001 & 0.0000 & 0.0900 & 0.9844 & 2.9277 \\
\hline \multirow{3}{*}{ Republic of Moldova } & EEI & 0.0484 & 0.0242 & 21.2805 & 0.0000 & 3.5546 \\
\hline & FRI & 0.0107 & 0.0054 & 4.7124 & 0.0226 & 3.5546 \\
\hline & Inter. & 0.0003 & 0.0001 & 0.0679 & 0.9908 & 2.9277 \\
\hline \multirow{3}{*}{ Russian Federation } & EEI & 0.0078 & 0.0039 & 16.8322 & 0.0001 & 3.5546 \\
\hline & FRI & 0.0136 & 0.0068 & 29.5217 & 0.0000 & 3.5546 \\
\hline & Inter. & 0.0000 & 0.0000 & 0.0539 & 0.9941 & 2.9277 \\
\hline \multirow{3}{*}{ Tajikistan } & EEI & 0.0385 & 0.0192 & 23.6779 & 0.0000 & 3.5546 \\
\hline & FRI & 0.0120 & 0.0060 & 7.3665 & 0.0046 & 3.5546 \\
\hline & Inter. & 0.0002 & 0.0001 & 0.0757 & 0.9887 & 2.9277 \\
\hline \multirow{3}{*}{ Turkmenistan } & EEI & 0.0484 & 0.0242 & 21.2805 & 0.0000 & 3.5546 \\
\hline & FRI & 0.0107 & 0.0054 & 4.7124 & 0.0226 & 3.5546 \\
\hline & Inter. & 0.0003 & 0.0001 & 0.0679 & 0.9908 & 2.9277 \\
\hline \multirow{3}{*}{ Ukraine } & EEI & 0.0302 & 0.0151 & 26.4869 & 0.0000 & 3.5546 \\
\hline & FRI & 0.0129 & 0.0065 & 11.3287 & 0.0007 & 3.5546 \\
\hline & Inter. & 0.0002 & 0.0000 & 0.0845 & 0.9861 & 2.9277 \\
\hline \multirow{3}{*}{ Uzbekistan } & EEI & 0.0178 & 0.0089 & 28.2788 & 0.0000 & 3.5546 \\
\hline & FRI & 0.0141 & 0.0070 & 22.3626 & 0.0000 & 3.5546 \\
\hline & Inter. & 0.0001 & 0.0000 & 0.0900 & 0.9844 & 2.9277 \\
\hline
\end{tabular}

Source: authors' elaboration.

Financial risk has the greatest impact (53-62\%) on the level of energy supply to socially vulnerable groups of the population in Azerbaijan, Kazakhstan, and Russia, and in the rest of the EECCA countries, the energy efficiency factor has a greater influence $(47-61 \%)$. The analysis allows us to conclude that in a number of the EECCA countries households are energy insecure and require the introduction of efficient technologies to provide housing services and the improvement of the implementation of household energy efficiency programs.

The methodological approach to assessing the level of energy supply to socially vulnerable segments of the population described in the study can be implemented in the standardized scheme of information and management systems in the context of building 
an economy focused on the population both in individual countries and in the EECCA region. This approach ensures the prompt identification of vulnerable consumers in the energy market in order to help state social protection authorities make management decisions. Efficient public management should be based on a mechanism for responding and overcoming the low level of energy supply to the population, which should take into account the relationship between social status and the actual results of the energy market reform. In the future, the interconnection of management activities of such systems can contribute to the development of programs to improve the living standard of the population of the countries considered on their path to building a socially oriented market economy.

\section{Discussion}

The methodological approach to assessing the level of energy supply to socially vulnerable segments of the population based on regional development modeling is an important element of determining the effectiveness of the socio-economic status for comparing countries and regions, as well as developing strategies for their development [40]. The need to compare the socio-economic development of regions is due to modern economy regionalization trends. The approach to modeling the assessment of the regional level of energy security through the prism of the energy supply indicator involves the formation of models for calculating the costs and volumes of consumption of fuel and energy resources by households in the countries under study [25]. The major advantage of the proposed approach is the availability of its practical application methods, which ensures the detection of problems of the socio-economic policy of the state for making adequate decisions in the context of liberalization of the energy market and transformation of the economic system. It is this model, which describes the level of financial risk of the population and energy efficiency as exogenous and endogenous parameters, that ensures functionality, that is, emergent properties of the model when forecasting and assessing the socio-economic development of countries and regions. Each direction includes a list of tasks to be solved, namely: mathematical calculation of the financial risk index of a household in the country's economy, the level of energy efficiency of households. At the same time, it is possible to develop alternative options for improving energy security: to substantiate the points of influence of the economic growth policy, to synthesize measures to ensure the specified indicators of economic growth and the pricing policy of the energy market [41].

Due to the fact that the development of the energy market in the EECCA region is characterized by the principle of encouraging measures that promote consumer protection through the use of instruments and measures of non-tariff methods of support (based on subsidies and individualized payments), as well as various non-financial protection measures, an adequate set of regulatory and social measures should become the basis for social planning and include the factual consumer vulnerability assessment [42]. Based on this, the available financial measures should be complemented by the non-financial ones. The development of a social action plan can also be the result of considerable consultations with stakeholders and the assessment of the government's ability to ensure the operation of the new protection system [43].

The methodology described in the study takes into account different approaches, according to which energy costs exceed a certain percentage of income. The methodological approach to the assessment of the integral index of energy supply to socially vulnerable segments of the population is an important element of ranking countries and regions in terms of energy security for the development and implementation of measures to overcome energy security threats in the context of building an economy focused on people [44]. The calculations have shown that the share of fuel and energy costs in household expenditure exceeds $10 \%$, which is the threshold of household income in most of the countries under consideration; this leads to the poor standard of living of the population and difficulties in meeting basic needs. A further increase in energy prices with no regard to the real income of the population will increase social tension. The methodology for determining 
the proposed integral indicator of energy supply to socially vulnerable segments of the population should be introduced at the institutional level and complement the integrated approach to the assessment of energy poverty [45].

The low real income of the population indicates the inefficiency of social policy, creates threats to the socio-economic security of the state, which is a qualitative characteristic of the economic system that should ensure proper living conditions for citizens, provide the population with resources for performing various types of economic activities, and consistently meet national interests [46]. It has been confirmed that untimely regulation of the impact of security factors can cause a change in their level; thus, they become destabilizing factors in the conditions of uncertainty, which is considered as a threat to economic security. Therefore, in order to prevent the transformation of risk factors into threats and avoid crisis situations, it is recommended to analyze the level of energy supply to socially vulnerable segments of the population [47]. Safeguards to protect vulnerable consumers should be included in the energy and social programs of the EECCA countries. The negative economic impact of leaps in energy prices on consumer groups necessitates an objective reassessment of energy consumers who receive subsidized assistance, and the development of a new social program to provide support for vulnerable energy consumers, which will allow the states to allocate funds to protect those social groups that actually need help in the context of growing energy prices. This is due to the fact that the coverage of the social protection system in the EECCA countries is rather wide today [48-50].

The limitation of the study is the disregard for the potential thermal regime indicator due to the lack of statistical data. However, this information can only be obtained by the direct survey of a large sample of households in all EECCA countries. This requires both heavy spending and the development of a set of technical indicators for surveying households as the data differ significantly depending on the type of household. Another matter that could affect the results obtained is insufficient attention paid to buildings' energy efficiency and leveling of the effectiveness of such incentives as subsidizing the poor in the context of energy supply and motivational policies to increase the use of renewable energy sources by households. The main prerequisite for these issues is the limited access to data, which hardly allows for a reflection of the real situation in the country.

The proposed methodology and algorithm for calculating the integral index of energy supply to socially vulnerable segments of the population in the EECCA region make it possible to calculate the constituent indicators of the energy efficiency of households. The approach to the establishment of threshold values to determine the level of energy security of the population allows us to highlight the problems related to socio-economic security. The careful analysis of the components of the integral indices of energy supply to socially vulnerable segments of the population makes it possible to identify problems and risks of energy security of both individual countries and the region, which should be taken into account in the process of developing a strategy for their economic development. Regional policy should be focused on meeting social and economic criteria: increasing employment and income of the population, ensuring the differentiation of energy resources, the introduction of energy efficient technologies, and improvement of subsidy programs in the context of supporting socially vulnerable segments of the population [51,52]. The hierarchy of these criteria determines the need for further research devoted to the assessment of the energy security of the region and the projection of indicators assessing its social and economic security.

This study presents an opportunity to model the integral index of energy supply to socially vulnerable population segments, but at the same time, fails to provide a systematic assessment of the impact of policies of the studied states. For this particular reason, future research can take a more in-depth look at the studied issue by evaluating the impact of political decisions on the energy supply to vulnerable social groups in order to form broad conclusions on possible decisions for strengthening, legitimizing or limiting social and energy policies in EECCA countries [53]. In addition, this research field can be expanded by assessing the level of energy supplies to socially unprotected population segments in other countries 
and regions and comparing the results. This will provide an opportunity not only to conduct a global study, but also to identify ways to improve public welfare in general.

\section{Conclusions}

Based on the indicators of energy costs and the level of residual household income in the EECCA countries, it can be argued that energy poverty is a problem in half of the countries studied. It has been estimated that most of the countries surveyed have exceeded the 10 percent threshold for energy costs. In 2019, countries such as Armenia, Azerbaijan, Kyrgyzstan, Belarus, Moldova, Tajikistan, Turkmenistan, Uzbekistan, Ukraine, and Georgia demonstrated poor energy security indicators. The population of Russia and Kazakhstan has adequate access to energy resources. Based on the approach that assumes that energy poverty arises when comparing residual income after the deduction of housing costs with the value of $60 \%$ of the average annual income of the population in the EECCA region, it can be argued that Azerbaijan, Armenia, Belarus, Georgia, Kazakhstan, Kyrgyzstan, Moldova, Tajikistan, Turkmenistan, Ukraine, and Uzbekistan are energy poor economies. The third approach that is based on the comparison of household threshold with the average threshold of residual income in the EECCA countries and the energy expenditure by an average household in the country also indicates that countries such as Armenia, Georgia, Kyrgyzstan, Moldova, Tajikistan, Turkmenistan, and Ukraine are energy poor.

Thus, based on the results of the three approaches to assessing the level of energy supply to the population of the EECCA countries, it has been revealed that its critical indicators are found in Armenia, Georgia, Kyrgyzstan, Moldova, Tajikistan, Turkmenistan, and Ukraine. This demonstrates that households in these countries are not able to meet their basic energy needs, namely: to maintain an adequate room temperature, to get enough energy to be used. At the same time, energy costs exceed a certain percentage of household income.

The values of the integral index of energy supply to the socially vulnerable population show that in most countries the financial risk index is higher than the energy efficiency index. At the same time, almost all the countries under study are in the critical energy insecurity zone. In the EECCA countries, the energy supply index ranges from 0.43 to 0.65 . The indicator is seriously affected by an increase in energy prices. The low value of the index confirms the poor level of the population income and the high level of household energy expenditure in the EECCA countries. The lack of energy supply in the EECCA countries is reflected in the fact that most countries are at financial risk. This clearly indicates the non-market energy prices for the population and the high level of energy price subsidization. However, in the EECCA countries, the income of the population cannot be described as high. This shows the lack of a fully fledged market mechanism for pricing fuel and energy resources that are directly consumed by the population, as well as the lack of an effective social policy. For the purpose of determining non-taxable income, it seems appropriate to use the concept of "compensation" (Art. 217 of the Tax Code of the Russian Federation), which takes into account the payments listed in the Labor Code of the Russian Federation, as well as all state payments to low-income citizens to compensate for utility bills.

Based on the multivariate analysis of variance, it can be concluded that in all EECCA countries both financial risk and energy efficiency levels are very important. Therefore, in these countries, it is necessary not only to ensure an adequate level of income but also to use energy resources in the context of the efficiency of their consumption. In Azerbaijan, Kazakhstan and Russia, financial risk has the greatest impact on the level of energy supply to socially vulnerable segments of the population, while in other EECCA countries the energy efficiency factor has the strongest impact. The analysis allows us to conclude that in a number of EECCA countries, households have poor energy supply and need an efficient and reliable operation, the introduction of energy-efficient technologies for home maintenance, and the improvement of related programs.

The methodological approach to assessing the level of energy supply to socially vulnerable segments of the population described in the study can be implemented in the standardized scheme of information and management systems in the context of building an 
economy focused on the population both in individual countries and in the EECCA region. This approach ensures the prompt identification of vulnerable consumers in the energy market in order to help state social protection authorities make management decisions. An efficient public policy should be based on a mechanism for responding and overcoming the low level of energy supply to the population, which should take into account the relationship between social status and the actual results of the energy market reform. In the future, the interconnection of management activities of such systems can contribute to the development of programs to improve the living standard of the population of the countries considered with the aim of building a socially oriented market economy.

Author Contributions: Conceptualization, E.S. and R.R.; methodology, V.S.; software, S.Y.; validation, E.S., S.Y., V.S. and R.R.; formal analysis, K.S.-W.; investigation, V.S.; resources, R.R.; data curation, S.Y.; writing—original draft preparation, E.S. and R.R.; writing—review and editing, K.S.-W. and V.S.; visualization, V.S. and S.Y.; supervision, K.S.-W. and E.S.; project administration, R.R. All authors have read and agreed to the published version of the manuscript.

Funding: The project is funded under the program of the Minister of Science and Higher Education titled "Regional Initiative of Excellence" in 2019-2022, project number 018/RID/2018/19, the amount of funding PLN 10788 423,16". The material was prepared within the framework of grant funding for young scientists of the Ministry of Education and Science of the Republic of Kazakhstan for 2020-2022 under the project AP08051865 "Legal and political mechanisms for effective state management of youth migration in the Republic of Kazakhstan: problems and prospects".

Institutional Review Board Statement: Not applicable.

Informed Consent Statement: Not applicable.

Data Availability Statement: Data will be available on request.

Conflicts of Interest: The authors declare no conflict of interest.

\section{References}

1. Bezpalov, V.V.; Lochan, S.A.; Fedyunin, D.V. The Signs of Economic Disparity in Russia Following the Implosion of the USSR. Visual Anthrop. 2020, 33, 116-127. [CrossRef]

2. Charlier, D.; Kahouli, S. From residential energy demand to fuel poverty: Income-induced non-linearities in the reactions of households to energy price fluctuations. Energy J. 2019, 40, 1-12. [CrossRef]

3. Štreimikienè, D.; Mikalauskienè, A.; Mikalauskas, I. Comparative Assessment of Sustainable Energy Development in the Czech Republic, Lithuania and Slovakia. J. Compet. 2016, 8, 31-41.

4. Robinson, C.; Lindley, S.; Bouzarovski, S. The spatially varying components of vulnerability to energy poverty. Ann. Am. Assoc. Geogr. 2019, 109, 1188-1207. [CrossRef]

5. Oláh, J.; Lengyel, P.; Balogh, P.; Harangi-Rákos, M.; Popp, J. The role of biofuels in food commodity prices volatility and land use. J. Compet. 2017, 9, 81-93. [CrossRef]

6. Tvaronavičienè, M.; Ślusarczyk, B. Energy Transformation towards Sustainability; Elsevier: Amsterdam, The Netherlands, 2019.

7. Widiyanti, M.; Sadalia, I.; Irawati, N.; Hendrawaty, E. Determining firm's performance: Moderating role of CSR in renewable energy sector of Indonesia. Pol. J. Manag. Stud. 2019, 19, 432-441.

8. Haseeb, M.; Kot, S.; Iqbal Hussain, H.; Kamarudin, F. The natural resources curse-economic growth hypotheses: Quantile-onQuantile evidence from top Asian economies. J. Clean. Prod. 2021, 279, 123596. [CrossRef]

9. Kasperowicz, R.; Bilan, Y.; Štreimikienè, D. The renewable energy and economic growth nexus in European countries. Sustain. Dev. 2020, 28, 1086-1093. [CrossRef]

10. Balitskiy, S.; Bilan, Y.; Strielkowski, W.; Štreimikiene, D. Energy efficiency and natural gas consumption in the context of economic development in the European Union. Renew. Sustain. Energy Rev. 2016, 55, 156-168. [CrossRef]

11. Sangroya, D.; Nayak, J.K. Factors influencing buying behaviour of green energy consumer. J. Clean. Prod. 2017, 151, 393-405. [CrossRef]

12. Kaiser, M.; Bernauer, M.; Sunstein, C.R.; Reisch, L.A. The power of green defaults: The impact of regional variation of opt-out tariffs on green energy demand in Germany. Ecol. Econ. 2020, 174, 106685. [CrossRef]

13. Safarzadeh, S.; Rasti-Barzoki, M. A duopolistic game for designing a comprehensive energy-efficiency scheme regarding consumer features: Which energy policy is the best? J. Clean. Prod. 2020, 255, 120195. [CrossRef]

14. Shi, Q.; Ren, H.; Cai, W.; Gao, J. How to set the proper level of carbon tax in the context of Chinese construction sector? A CGE analysis. J. Clean. Prod. 2019, 240, 117955. [CrossRef] 
15. Ortiz, M.; Itard, L.; Bluyssen, P.M. Indoor environmental quality related risk factors with energy-efficient retrofitting of housing: A literature review. Energy Build. 2020, 221, 110102. [CrossRef]

16. Trotta, G. Factors affecting energy-saving behaviours and energy efficiency investments in British households. Energy Policy 2018, 114, 529-539. [CrossRef]

17. Grossmann, K. Using conflicts to uncover injustices in energy transitions: The case of social impacts of energy efficiency policies in the housing sector in Germany. Glob. Transit. 2019, 1, 148-156. [CrossRef]

18. $\mathrm{Xu}, \mathrm{X}$; Chen, C.F. Energy efficiency and energy justice for US low-income households: An analysis of multifaceted challenges and potential. Energy Policy 2019, 128, 763-774. [CrossRef]

19. Thomson, H.; Bouzarovski, S. Addressing Energy Poverty in the European Union: State of Play and Action; EU Energy Poverty Observatory: Manchester, UK, 2018.

20. Sharma, S.V.; Han, P.; Sharma, V.K. Socio-economic determinants of energy poverty amongst Indian households: A case study of Mumbai. Energy Policy 2019, 132, 1184-1190. [CrossRef]

21. Zhang, D.; Li, J.; Han, P. A multidimensional measure of energy poverty in China and its impacts on health: An empirical study based on the China family panel studies. Energy Policy 2019, 131, 72-81. [CrossRef]

22. Kose, T. Energy poverty and health: The Turkish case. Energy Sources Part B 2019, 14, 201-213.

23. Primc, K.; Slabe-Erker, R. Social policy or energy policy? Time to reconsider energy poverty policies. Energy Sustain. Dev. 2020, 55, 32-36. [CrossRef]

24. Balitskiy, S.; Bilan, Y.; Strielkowski, W. Energy security and economic growth in the European Union. J. Secur. Sustain. Issues 2014, 4, 123-130. [CrossRef]

25. Sareen, S.; Thomson, H.; Herrero, S.T.; Gouveia, J.P.; Lippert, I.; Lis, A. European energy poverty metrics: Scales, prospects and limits. Glob. Transit. 2020, 2, 26-36. [CrossRef]

26. Urquiza, A.; Amigo, C.; Billi, M.; Calvo, R.; Labraña, J.; Oyarzún, T.; Valencia, F. Quality as a hidden dimension of energy poverty in middle-development countries. Literature review and case study from Chile. Energy Build. 2019, 204, 109463. [CrossRef]

27. Karpinska, L.; Śmiech, S. Conceptualising housing costs: The hidden face of energy poverty in Poland. Energy Policy 2020, 147, 111819. [CrossRef]

28. Burlinson, A.; Giulietti, M.; Battisti, G. The elephant in the energy room: Establishing the nexus between housing poverty and fuel poverty. Energy Econ. 2018, 72, 135-144. [CrossRef]

29. Gillard, R.; Snell, C.; Bevan, M. Advancing an energy justice perspective of fuel poverty: Household vulnerability and domestic retrofit policy in the United Kingdom. Energy Res. Soc. Sci. 2017, 29, 53-61. [CrossRef]

30. Churchill, S.A.; Smyth, R.; Farrell, L. Fuel poverty and subjective wellbeing. Energy Econ. 2020, 86, 104650. [CrossRef]

31. Sadath, A.C.; Acharya, R.H. Assessing the extent and intensity of energy poverty using Multidimensional Energy Poverty Index: Empirical evidence from households in India. Energy Policy 2017, 102, 540-550. [CrossRef]

32. Tvaronavičienè, M.; Prakapienè, D.; Garškaitè-Milvydienè, K.; Prakapas, R.; Nawrot, Ł. Energy efficiency in the long run in the selected European countries. Econ. Sociol. 2018, 11, 245-254. [CrossRef] [PubMed]

33. Acharya, R.H.; Sadath, A.C. Energy poverty and economic development: Household-level evidence from India. Energy Build. 2019, 183, 785-791. [CrossRef]

34. Yang, Y.C.; Nie, P.Y.; Liu, H.T.; Shen, M.H. On the welfare effects of subsidy game for renewable energy investment: Toward a dynamic equilibrium model. Renew. Energy 2018, 121, 420-428. [CrossRef]

35. Papada, L.; Kaliampakos, D. A Stochastic Model for energy poverty analysis. Energy Policy 2018, 116, 153-164. [CrossRef]

36. Sánchez, C.S.G.; González, F.J.N.; Aja, A.H. Energy poverty methodology based on minimal thermal habitability conditions for low income housing in Spain. Energy Build. 2018, 169, 127-140. [CrossRef]

37. United Nations. Household Size \& Composition. 2019. Available online: https://population.un.org/Household/index.html\# /countries / 643 (accessed on 15 December 2020).

38. Pysar, N.; Dergacheva, V.; Bandura, A.; Pásztorová, J. Composite fuel poverty index as a means to assess energy security of the country. Economicannals-XXI 2018, 169, 50-56. [CrossRef]

39. The Legatum Prosperity Index. 2020. Available online: https://www.prosperity.com/rankings (accessed on 25 February 2021).

40. Monyei, C.G.; Adewumi, A.O.; Obolo, M.O.; Sajou, B. Nigeria's energy poverty: Insights and implications for smart policies and framework towards a smart Nigeria electricity network. Renew. Sustain. Energy Rev. 2018, 81, 1582-1601. [CrossRef]

41. Laldjebaev, M.; Morreale, S.J.; Sovacool, B.K.; Kassam, K.A.S. Rethinking energy security and services in practice: National vulnerability and three energy pathways in Tajikistan. Energy Policy 2018, 114, 39-50. [CrossRef]

42. Lapinskiene, G.; Tvaronavičiene, M.; Vaitkus, P. Greenhouse gases emissions and economic growth-evidence substantiating the presence of environmental Kuznets curve in the EU. Technol. Econ. Dev. Econ. 2014, 20, 65-78. [CrossRef]

43. Bedi, H.P. 'Our energy, our rights': National extraction legacies and contested energy justice futures in Bangladesh. Energy Res. Soc. Sci. 2018, 41, 168-175. [CrossRef]

44. Khattak, M.A.; Yahya, T.M.H.T.; Sallehhudin, M.W.M.; Ghazali, M.I.M.; Abdullah, N.A.; Nordin, N.A.; Dzakurnain, N.A.M.M.; Kazi, S. Global energy security and Eastern Europe: A review. J. Adv. Res. Des. 2018, 45, 19-42.

45. Castaño-Rosa, R.; Solís-Guzmán, J.; Rubio-Bellido, C.; Marrero, M. Towards a multiple-indicator approach to energy poverty in the European Union: A review. Energy Build. 2019, 193, 36-48. [CrossRef] 
46. Yao, L.; Shi, X.; Andrews-Speed, P. Conceptualization of energy security in resource-poor economies: The role of the nature of economy. Energy Policy 2018, 114, 394-402. [CrossRef]

47. Glemarec, Y. Aligning national interests and global climate justice: The role of human rights in enhancing the ambition of nationally determined contributions to combat climate change. FJHSS 2019, 12, 309-327. [CrossRef]

48. Anderson, E.; d'Orey, M.A.J.; Duvendack, M.; Esposito, L. Does government spending affect income poverty? A meta-regression analysis. World Dev. 2018, 103, 60-71. [CrossRef]

49. Saługa, P.W.; Szczepańska-Woszczyna, K.; Miśkiewicz, R.; Chład, M. Cost of equity of coal-fired power generation projects in poland: Its importance for the management of decision-making process. Energies 2020, 13, 4833. [CrossRef]

50. Dróżdż, W.; Marszałek-Kawa, J.; Miśkiewicz, R.; Szczepańska-Woszczyna, K. Digital Economy in the Contemporary World; Adam Wydawnictwo Marszałek: Torun, Poland, 2020.

51. Smirnova, E.E. Tax risks of economic entities in the digital economy. Finance 2019, 1, 26-29.

52. Grondys, K.; Androniceanu, A.; Dacko-Pikiewicz, Z. Energy Management in the Operation of Enterprises in the Light of the Applicable Provisions of the Energy Efficiency Directive (2012/27/EU). Energies 2020, 13, 4338. [CrossRef]

53. Katsuba, S.; Shestak, V.; Kvasnikova, T.; Bokov, Y. Liability for Violation of Environmental Legislation in the EU. Eur. Energy Environ. Law Rev. 2021, 30, 9-19. 